\title{
Characterization of nitrate reductase activity in vitro in Gracilaria caudata J.Agardh (Rhodophyta, Gracilariales)
}

\author{
FUNGYI CHOW $^{1,2}$, FERNANDA V. CAPOCIAMA ${ }^{1}$, RENATA FARIA ${ }^{1}$ and \\ MARIANA C. DE OLIVEIRA ${ }^{1}$
}

(received:August 18, 2005; accepted: February 8, 2007)

\begin{abstract}
Characterization of nitrate reductase activity in vitro in Gracilaria caudata J. Agardh (Rhodophyta, Gracilariales)). The marine red alga Gracilaria caudata J. Agardh has been used in Brazil for agar extraction, mainly in the northeast region of the country. Nitrogen availability is the most important abiotic factor in seawater that limits the growth of seaweeds. The enzyme nitrate reductase (NR) is the key regulatory point in the nitrogen assimilation in photosynthetic organisms. This study describes an in vitro assay, characterizing the enzymatic activity of NR in terms of kinetic constants and stability, its oscillation during the day and glucose effect on NR modulation. Maximal peaks of NR activity were recorded at $20{ }^{\circ} \mathrm{C}$ and $\mathrm{pH}$ 8.0. The enzymatic stability in crude extracts stored at $3 \pm 1{ }^{\circ} \mathrm{C}$ decreased significantly after 48 hours. Apparent Michaelis-Menten constants $\left(\mathrm{K}_{\mathrm{M}}\right)$ for NADH and nitrate were $22 \mu \mathrm{M}$ and $3.95 \mathrm{mM}$, respectively. Gracilaria caudata NR activity showed an oscillation under light:dark photoperiod (14:10 hours LD) with 3-fold higher activity during the light phase, peaking after 10 hours of light. Under optimal assay conditions, the maximal activity was $92.910^{-3} \mathrm{U} \mathrm{g}^{-1}$. The addition of glucose induced the enzymatic activity during the light and dark phase, evidencing a possible modulation of this enzyme by the photosynthesis. This relationship can be explained by the need of carbon skeletons, produced by the photosynthetic process, to incorporate the intermediary metabolites of nitrate assimilatory pathway, avoiding the toxic intracellular accumulation of nitrite and ammonium. The optimization of enzymatic assay protocols for NR is essential to establish appropriate conditions to study nutritional behaviour, compare different taxonomic groups and to understand its regulatory mechanism.
\end{abstract}

Key words - agarophyte, Gracilaria caudata, nitrate reductase, nitrogen metabolism

RESUMO - (Caracterização da atividade in vitro da enzima nitrato redutase em Gracilaria caudata J. Agardh (Gracilariales, Rhodophyta)). A alga vermelha Gracilaria caudata J. Agardh tem sido utilizada no Brasil para a extração de ágar, principalmente no Nordeste do país. Na água do mar, a disponibilidade de nitrogênio é o principal fator abiótico que limita o crescimento de macroalgas. A enzima nitrato redutase (NR) é o ponto chave na regulação da assimilação do nitrogênio em organismos fotossintetizantes. Este estudo descreve o ensaio in vitro para caracterizar a atividade enzimática da NR em termos de constantes cinéticas e estabilidade, avalia sua oscilação ao longo do dia e a influência da glicose na modulação dessa enzima. Picos máximos de atividade da NR foram observados a $20^{\circ} \mathrm{C} \mathrm{e} \mathrm{pH} \mathrm{8,0.} \mathrm{A} \mathrm{estabilidade} \mathrm{enzimática} \mathrm{do} \mathrm{extrato} \mathrm{bruto} \mathrm{armazenado} \mathrm{a} 3 \pm 1{ }^{\circ} \mathrm{C}$ foi significativamente reduzida após 48 horas. As constantes aparentes de Michaelis-Menten $\left(\mathrm{K}_{\mathrm{M}}\right)$ para NADH e nitrato foram $22 \mu \mathrm{M}$ e 3,95 mM, respectivamente. A atividade da NR apresentou oscilação sob fotoperíodo de 14 horas de luz e10 horas de escuro com três vezes mais atividade durante a fase de luz, apresentando seu máximo após 10 horas de luz. Sob condições ótimas de ensaio, a atividade máxima foi de $92,910^{-3} \mathrm{U} \mathrm{g}^{-1}$. A adição de glicose induziu a atividade da NR durante as fases de luz e de escuro, evidenciando uma via de modulação dessa enzima pela fotossíntese. Essa relação pode ser explicada pela necessidade de esqueletos de carbono, fornecidos pela fotossíntese, para incorporar os metabólitos intermediários da via de assimilação do nitrato, evitando assim a toxicidade intracelular pela acumulação de nitrito e amônio. A otimização dos protocolos de ensaio enzimático para NR é essencial para estabelecer condições apropriadas para estudos nutricionais, comparar diferentes grupos taxonômicos, e entender os mecanismos de sua regulação.

Palavras-chave - agarófita, Gracilaria caudata, metabolismo do nitrogênio, nitrato redutase

\section{Introduction}

Nitrogen is the most important abiotic factor that limits the algal growth in the marine environment (Lobban \& Harrison 1994, Oliveira \& Plastino 1994)

\footnotetext{
1. Universidade de São Paulo, Instituto de Biociências, Caixa Postal 11461, 05422-970 São Paulo, SP, Brazil.

2. Corresponding author: fchow@ib.usp.br
}

and its main available source is in the form of nitrate $\left(\mathrm{NO}_{3}{ }^{-}\right)$(Chapman \& Harrison 1988). The assimilation of nitrate involves its cytoplasmatic reduction to nitrite $\left(\mathrm{NO}_{2}{ }^{-}\right)$, catalyzed by the enzyme nitrate reductase (NR), using $\mathrm{NAD}(\mathrm{P}) \mathrm{H}$ as electron donor. In the chloroplasts, nitrite is quickly reduced to ammonium $\left(\mathrm{NH}_{4}^{+}\right)$by the enzyme nitrite reductase (NiR) that uses ferredoxine as electron donor, and ammonium is then incorporated to nitrogen molecules as amino acids, purines, pirimidines and amines (Lea \& Leegood 1995). 
The enzyme NR is a flavoprotein of high molecular weight, composed by identical subunits containing three prosthetic groups: flavin adenine dinucleotide (FAD), cytochrome b557 (heme) and molybdenum cofactor (MoCo) (Lea \& Leegood 1995). There are three forms of NR in eukaryotes: (a) NADH-specific, in most of the plants and some algae; (b) bispecific for $\mathrm{NAD}(\mathrm{P}) \mathrm{H}$, in some plants (usually monocotyledons), some algae and fungi; and (c) NADPH-specific, in fungi (Campbell 1999).

The NR activity is regulated by several environmental and intracellular factors, such as light quantity and quality, concentration of nitrogen compounds, $\mathrm{CO}_{2}$, molybdenum, iron, biological clock, phytohormones, plastidic factors, and carbon metabolites (Crawford \& Arst Junior1993, Lea \& Leegood 1995). Many studies have demonstrated that NR activity can vary with light regimes, showing circadian fluctuations with diurnal assimilatory peaks (Ramus 1981, Edmunds Junior 1988, Lopes et al. 1997, Rossa 1999, Chow et al. 2004). The regulation of this enzyme involves protein synthesis and degradation cycles (Solomonson \& Barber 1990), control by redox and allosteric modulation (Kaiser \& Brendle-Behnisch 1991), and phosphorylation and dephosphorylation processes (Huber et al. 1992). The intermediaries of nitrogen assimilatory pathway, nitrite and ammonium, are toxic and mutagenic. Therefore, they must be quickly incorporated to carbon skeletons provided by the photosynthetic process to avoid their accumulation into the cells (Huppe \& Turpin 1994, Chow 2002). This complex regulation serves to integrate nitrate assimilation with photosynthesis and carbon metabolism (Crawford \& Arst Junior 1993).

The genus Gracilaria Greville (Rhodophyta, Gracilariales) includes about 100 species widely distributed in the world (Oliveira \& Plastino 1994) and Gracilaria caudata J. Agardh is one of the most common species in tropical and subtropical Atlantic Ocean. This species is exploited as an important agarophyte in northeastern Brazil (Oliveira \& Alveal 1990). Therefore, there is a great interest to study the nutritional and growth mechanisms of this seaweed.

This study describes an in vitro assay method to quantify NR activity in the agarophyte G. caudata. The optimized assay was used to characterize the enzymatic activity in terms of kinetic constants and stability. Activity oscillation and glucose effect on NR modulation were also evaluated.

\section{Material and methods}

Culture - Gracilaria caudata was collected in Martim de Sá Beach (Caraguatatuba, São Paulo, Brazil) and cultivated under unialgal conditions in sterile seawater enriched with $50 \%$ von Stosch (VS) medium (Edwards 1970) at $25 \pm 1{ }^{\circ} \mathrm{C}, 65 \pm$ $6 \mu \mathrm{mol}$ photons $\mathrm{m}^{-2} \mathrm{~s}^{-1}$, light:dark (LD) photoperiod of 14:10 hours, salinity of $32 \mathrm{~g} \mathrm{~L}^{-1}$, and intermittent air bubbling 30:30 min (on:off). The renewal of culture medium and algal cleaning were performed once a week. Contamination by cyanobacteria and other bacteria were controlled by addition of potassic $\mathrm{G}$ penicillin (Fluka, Buchs) at $25 \mathrm{mg} \mathrm{L}^{-1}$ (Hoshaw \& Rodowski 1973) or amplicillin (Sigma, St. Louis, MO, USA) at $50 \mathrm{mg} \mathrm{L}^{-1}$ for 48 hours (Oliveira et al. 1995). Germanium dioxide (Merck, Frankfurt) at $2 \mathrm{mg} \mathrm{L}^{-1}$ was used to control diatom contamination (Lewin 1966).

Enzymatic assay of nitrate reductase - All experiments were performed with unbranched tips of $1.5 \mathrm{~cm}$ of length of algae previously grown in $50 \%$ VS for 24 hours. The samples were frozen in liquid nitrogen and stored at $-80{ }^{\circ} \mathrm{C}$ until the in vitro enzymatic assay (maximum 1 month). The samples were ground in liquid nitrogen to a fine powder and suspended in the standard extraction buffer ( $0.2 \mathrm{M}$ phosphate buffer, $\mathrm{pH} 8.0$; $5 \mathrm{mM}$ EDTA; $1 \mathrm{mMDTT}$ and $0.3 \% \mathrm{w} / \mathrm{v} \mathrm{BSA}$ ) at a concentration of $1 \mathrm{~g}$ wet weight per $5 \mathrm{~mL}$ of buffer. Cell debris was removed by centrifugation at $12,000 \mathrm{~g}$ for 15 minutes at $4{ }^{\circ} \mathrm{C}$. The supernatant (crude extract) was recovered and kept on ice until the NR activity was assayed (maximum 1 hour, except for the stability experiment). Nitrate reductase activity was determined by pre-incubating the crude extracts in the reaction mixture $\left(0.2 \mathrm{M}\right.$ phosphate buffer, $\mathrm{pH} 8.0 ; 6 \mathrm{mM} \mathrm{KNO}_{3}$ and $0.5 \mathrm{mM} \mathrm{MgSO}_{4}$ ) at $20^{\circ} \mathrm{C}$ for 10 minutes. The mixture was then incubated for another 5 minutes after addition of $0.02 \mathrm{mM}$ $\mathrm{NADH}$. Controls without NADH were prepared for each experiment. The enzymatic reaction was interrupted by adding $1.4 \mathrm{mM} \mathrm{ZnSO}_{4}$ and $43 \%$ v/v ethanol. Precipitates were removed by centrifugation at $12,000 \mathrm{~g}$ for 10 minutes at $20^{\circ} \mathrm{C}$. Nitrite concentrations were determined by measuring absorption at $543 \mathrm{~nm}$ after the addition of $9.6 \mathrm{mM}$ sulphanilamide and $0.7 \mathrm{mM} n$-(1-naphtyl)ethylenediamine dihydrochloride. One unit of NR (U) is the enzymatic activity producing $1 \mu \mathrm{mol}$ of nitrite per minute at $20^{\circ} \mathrm{C}$ (Chapman \& Harrison 1988).

The in vitro NR assay method for $G$. caudata was standardized by testing several parameters. (a) methods to interrupt the enzymatic reaction $\left(1.4 \mathrm{mM} \mathrm{ZnSO}_{4}\right.$ and $43 \% \mathrm{v} / \mathrm{v}$ ethanol; $1.4 \mathrm{mM} \mathrm{ZnSO}_{4}$ and 3 minutes boiling; $14 \mathrm{mM} \mathrm{ZnSO}_{4}$; $1.4 \mathrm{mM} \mathrm{ZnSO}_{4}$ and 3 minutes boiling); (b) assay incubation time (5, 10 and 15 minutes); (c) apical $(1.5 \mathrm{~cm})$ and basal $(1.5 \mathrm{~cm}$ immediately below) segments; (d) NADH $(0-250 \mu \mathrm{M})$ and nitrate $(0-40 \mathrm{mM})$ concentrations; (e) optimal $\mathrm{pH}$ and temperature; and (f) stability of NR activity by storing the crude extract at $3 \pm 1{ }^{\circ} \mathrm{C}$ for up to three days. The effect of nitrate on NR activity was performed in dialysed crude 
extracts. $\mathrm{K}_{\mathrm{M}}$ values for NADH and nitrate were calculated using the software ENZFITTER v.1.05 described by Leatherbarrow (1990) and using the Lineweaver-Burk plots.

Oscillation of NR activity during 24 hours was evaluated from apical segments kept in a LD cycle (14:10 hours) under the standard culture conditions described above. Light was turned on at time zero (T0). Samples of $70 \mathrm{mg}$ were collected every 2 hours and immediately frozen in liquid $\mathrm{N}_{2}$. Nitrate reductase assay was performed as described above. Glucose $(2 \% \mathrm{w} / \mathrm{v})$ in VS medium was added to unbranched tips of G. caudata either 1 hour or 24 hours before the samples of $70 \mathrm{mg}$ were collected during the light (T8) and dark phase (T18). Samples were immediately frozen in liquid $\mathrm{N}_{2}$ and nitrate reductase assay was performed as described above.

Statistical significances were analysed by Student test and one-way ANOVA with a probability of 95\% (Zar 1999). When necessary, an a posteriori Newman-Keuls test was performed. The means \pm standard deviations (SD) were based on triplicate measurements from one crude extract. The inference on pseudoreplicate data is usual in biochemistry studies and present an estimate of the variation related the methodology (Hurlbert 1984).

\section{Results}

The addition of $1.4 \mathrm{mMZnSO}_{4}$ and $43 \% \mathrm{v} / \mathrm{v}$ ethanol to the in vitro NR assay was the most efficient procedure to interrupt the nitrate reduction (data not shown). An incubation period of up to 10 minutes during the enzymatic assay was proportional and linear to nitrite production (figure 1). Basal segments of the thalli showed only $72 \%$ of activity compared to apical segments. Maximal NR activities were observed at $\mathrm{pH}$

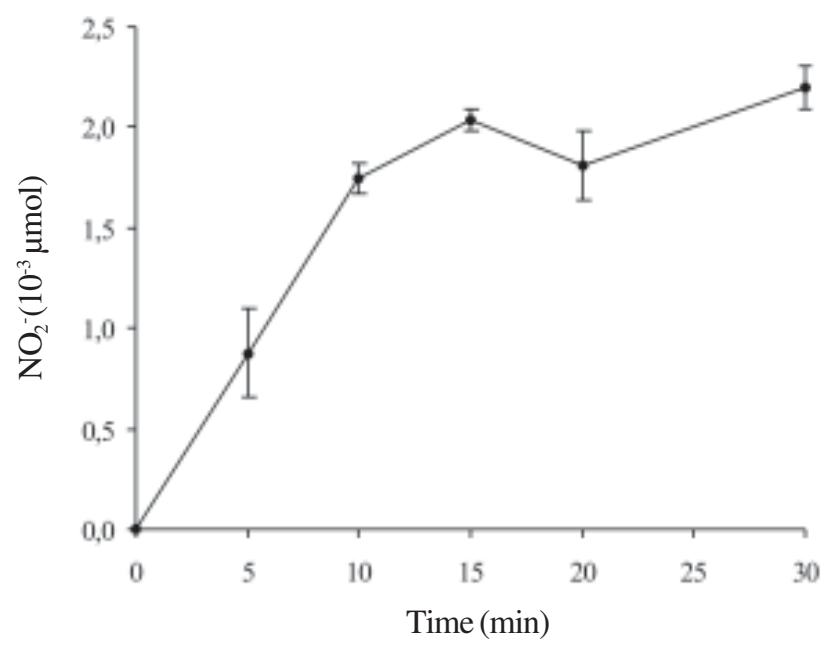

Figure 1. Nitrite concentration produced in the in vitro reduction of nitrate by nitrate reductase (NR) activity. Means $\pm \mathrm{SD}$ (three measurements from the same crude extract). $8.0\left(24.21 \pm 3.1410^{-3} \mathrm{U} \mathrm{g}^{-1}\right.$; figure $\left.2 \mathrm{~A}\right)$ and $20^{\circ} \mathrm{C}(38.65$ $\pm 4.1610^{-3} \mathrm{U} \mathrm{g}^{-1}$; figure $\left.2 \mathrm{~B}\right)$. Storing crude extracts at $3 \pm 1{ }^{\circ} \mathrm{C}$ decreased the enzymatic activity significantly by approximately $50 \%$ after 24 hours and only $16 \%$ activity remained after 48 hours (data not shown). The apparent $\mathrm{K}_{\mathrm{M}}$ value for NADH was $22 \mu \mathrm{M}$, and for nitrate was $3.95 \mathrm{mM}$ (table 1). The addition of concentrations higher than $80 \mu \mathrm{M}$ NADH inhibited the $\mathrm{NR}$ activity (figure $3 \mathrm{~A}$ ) and $30 \mathrm{mM}$ nitrate reduced the NR activity (figure 3B). Lower activity levels of 7\% and $20 \%$ in relation to the controls were observed when $\mathrm{NADPH}$ or $\mathrm{Mg}^{2+}$ was added, respectively. The highest NR activity (92.9 $10^{-3} \mathrm{U} \mathrm{g}^{-1}$; table 1) was registered when $50 \%$ VS was added 24 hours before the extraction assay under standard culture conditions and optimal assay conditions (see materials and methods).
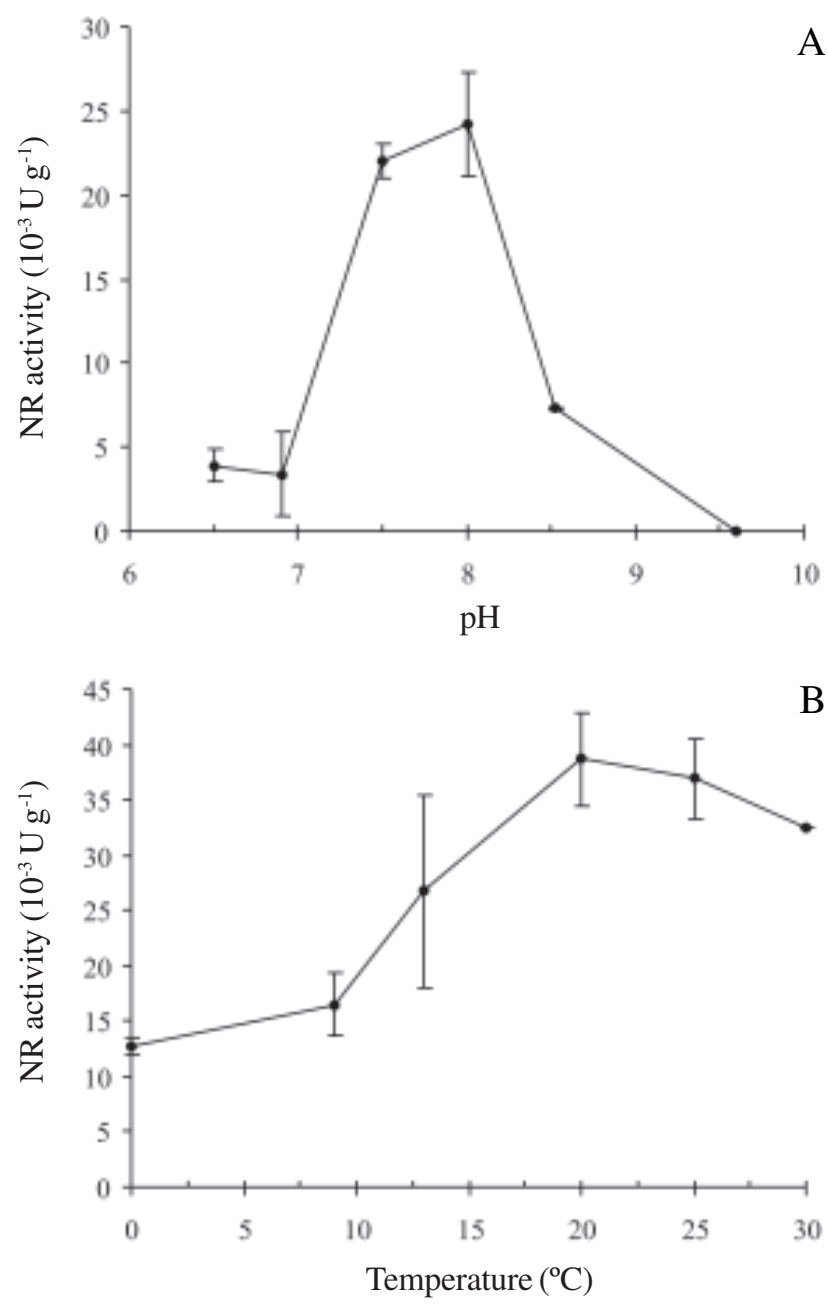

Figure 2. Nitrate reductase (NR) activity under different levels of (A) $\mathrm{pH}$ and (B) temperature in the red seaweed Gracilaria caudate. Means \pm SD (three measurements from the same crude extract). 


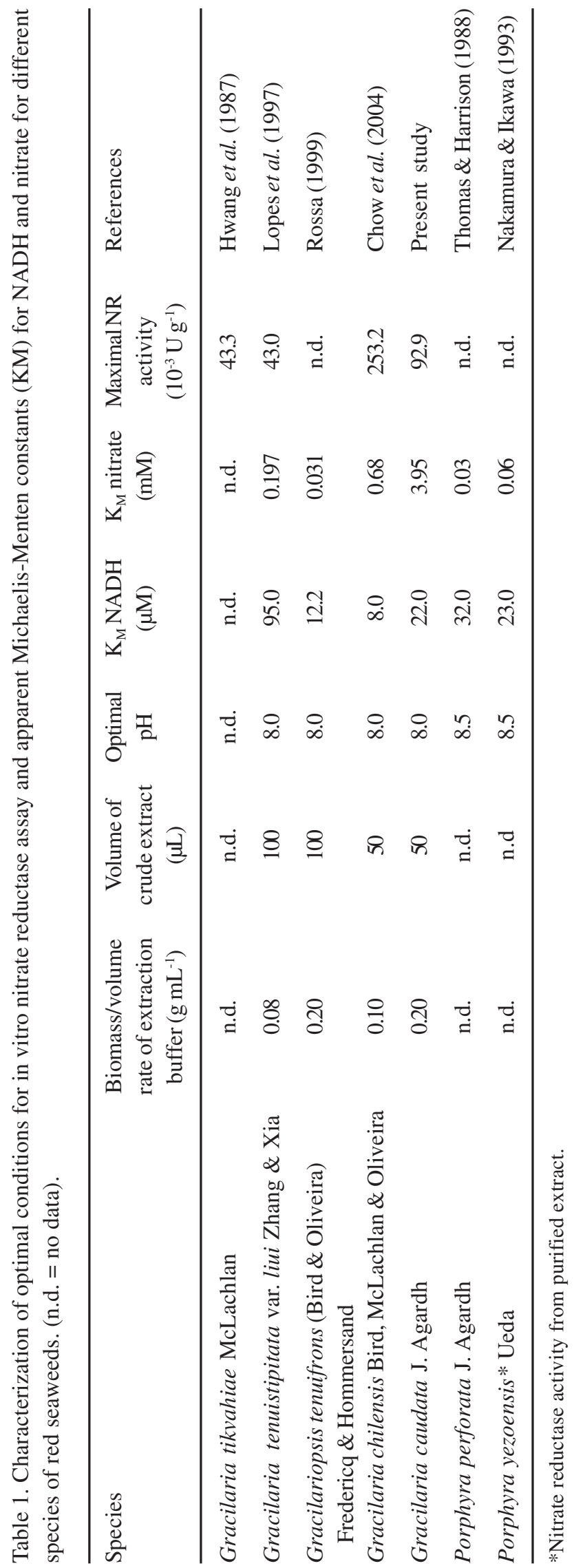

Algae grown under LD (14:10 hours) photoperiod showed NR activity oscillation with lower levels of activity during the dark phase. The maximal NR activity peak was observed after 10 hours of light (T10) and was three times higher than the activity observed during the dark (figure 4). The addition of glucose one hour before NR assay showed no influence on NR activity (data not shown), but the addition of glucose 24 hours before NR assay induced the enzymatic activity both in light and dark phases by $43 \%$ and $55 \%$, respectively (figure 5).

\section{Discussion}

Despite the importance of nitrogen and presence of the enzyme NR in seaweeds, little is know about its
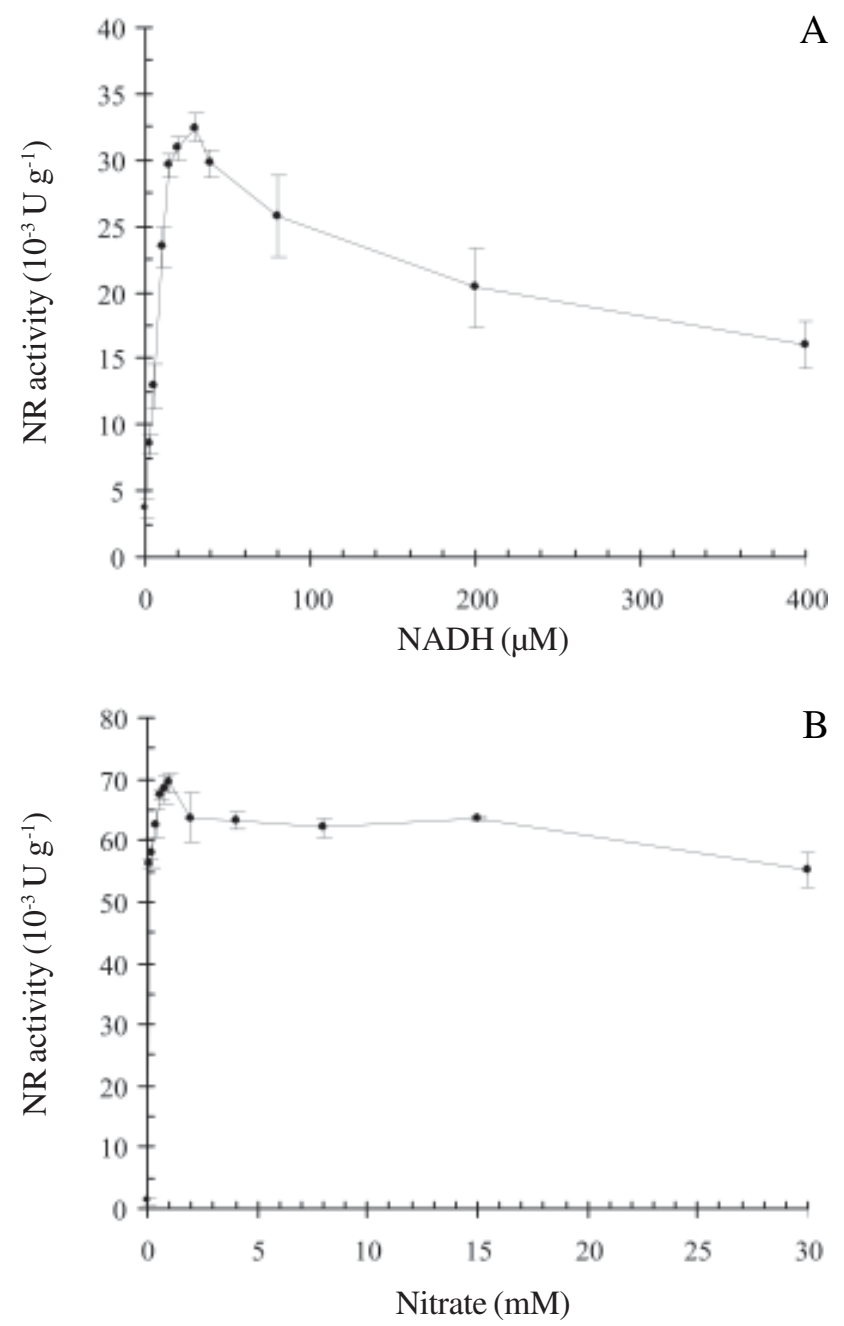

Figure 3. Effect of different concentrations of (A) NADH and (B) nitrate on nitrate reductase (NR) activity in the red seaweed Gracilaria caudate. Means \pm SD (three measurements from the same crude extract). 


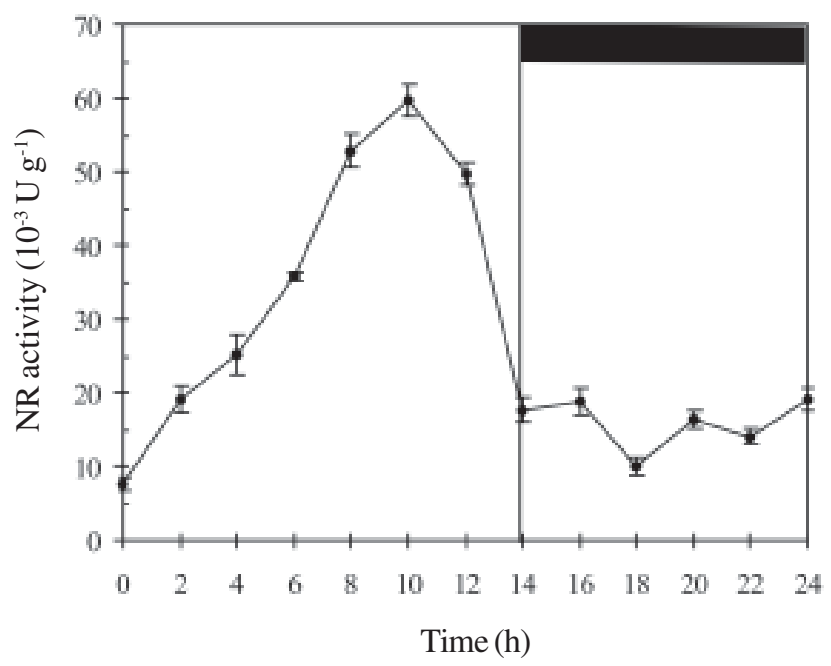

Figure 4. Oscillation of in vitro nitrate reductase (NR) activity under light:dark photoperiod $(14: 10 \mathrm{~h})$ in the red seaweed Gracilaria caudate. Black bar represents dark phase. Means \pm SD (three measurements from the same crude extract).

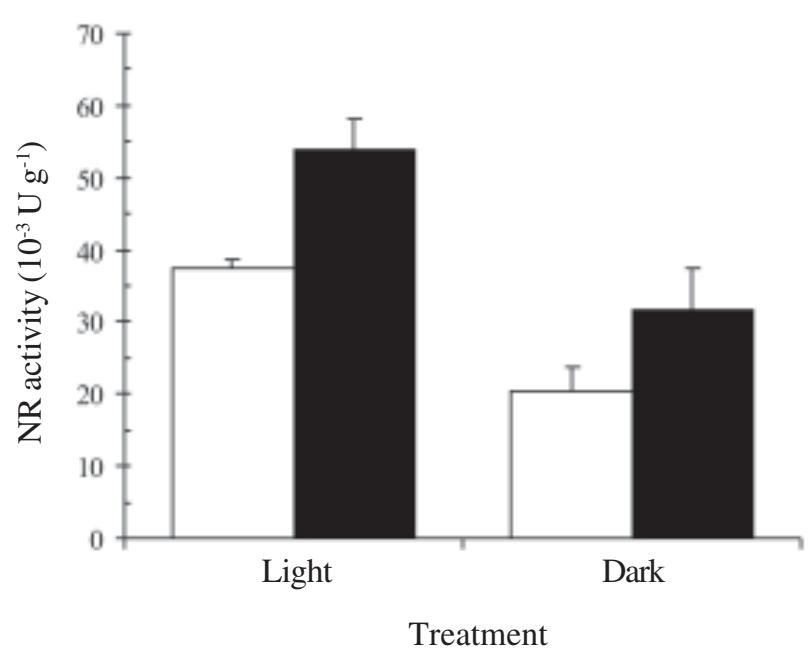

Figure 5. Effect of glucose addition ( $2 \% \mathrm{w} / \mathrm{v})$ during the light and dark phases on nitrate reductase (NR) activity in the red seaweed Gracilaria caudate. White bars represent controls without glucose addition, and black bars with glucose addition. Means \pm SD (three measurements from the same crude extract).

metabolism, when compared to the extensive information available for higher plants and microalgae. Nitrate reductase shows great variations among photosynthetic organisms evidenced by different levels of requested substrate (nitrate and $\mathrm{NADH}$ ) to reach the maximal activity and the effect of many regulating factors, such as light quantity and quality. Therefore, different extraction protocols result in a wide variation of enzymatic activities (Berges \& Harrison 1995), being essential to establish optimal assay conditions for each species (Thomas \& Harrison 1988, Hurd et al. 1995, Chow et al. 2004). To optimize an assay method for Gracilaria caudata, variations in the methodology described by Thomas \& Harrison (1988) and Lopes et al. (1997) were tested.

The high NR activity recorded for G. caudata, compared to some other species (table 1), evidences the optimized protocol for this species. Key steps in the protocol optimization were a extensive extraction of the enzyme by grinding the samples in liquid nitrogen and the preservation of its activity by addition of compounds that minimize protein degradation (e.g. EDTA, DTT, and BSA). The high NR activity is also due to the addition of NADH and nitrate in saturating amounts, avoiding sub-optimal or inhibitory conditions for the assay. The main modifications in the protocol registered for different species of Gracilaria are: (a) the rate of fresh weight per volume of extraction buffer, and (b) volume of crude extract used for each incubation (table 1). These differences indicate the variable physiological state of each species determined by the amount of internal stored nitrogen (e.g. proteins, amino acids, phycobilins and Rubisco) and, therefore, affecting the level of available NR enzyme.

The optimal $\mathrm{pH}$ for G. caudata NR was 8.0, the same found for other species of seaweed, higher than found in higher plants ( $\mathrm{pH} 7.5)$, but similar to seawater $\mathrm{pH}$ (8.2). Gracilaria caudata NR is active in a wide range of temperatures (from 0 to $30{ }^{\circ} \mathrm{C}$ ), similar to observed for G. tenuistipitata var. liui (Lopes et al. 1997). These species are tropical and subtropical, therefore, their tolerance to both $\mathrm{pH}$ and temperature ranges may be related to their natural geographic distribution.

According to Berges \& Harrison (1995), there are species-specific differences on kinetic parameters for $\mathrm{NADH}$ and nitrate. The apparent $\mathrm{K}_{\mathrm{M}}$ for $\mathrm{NADH}$ in G. caudata $(22 \pm 7 \mu \mathrm{M})$ is closer to those of Porphyra perforata $(32 \pm 9 \mu \mathrm{M}$; Thomas \& Harrison 1988) and P. yezoensis ( $23 \mu \mathrm{M}$; Nakamura \& Ikawa 1993). On the other hand, the value for nitrate $\mathrm{K}_{\mathrm{M}}$ was much higher for $G$. caudata than for other tested red seaweeds. The differences in the $K_{M}$ values for NADH and nitrate are related to the particular characteristics of metabolic capacity of each species, and associated to laboratory culture conditions that determine the nutrient availability (stocked into the vacuoles or as organic molecules). 
The low NR activity registered with NADPH as electron donor did not agree to the data in the literature for other red seaweeds that showed no activity when NADPH was added (Nakamura \& Ikawa 1993, Lopes et al. 1997). This NADPH-activity could be explained by the presence of another NADPH-activated isoenzyme, by dephosphorylation of NADPH to $\mathrm{NADH}$, or conversion of NADPH in NADH by a transhydrogenase (Jackson 1991). Berges \& Harrison (1995) described that this transhydrogenase could be present in crude extracts, and NADPH would be converted to NADH and then used by a NADHspecific NR. However, it is more common in homogenates that are not centrifuged, which is not the case for G. caudata, once the crude extract was centrifuged.

The maximal NR activity $\left(92.910^{-3} \mathrm{U} \mathrm{g}^{-1}\right)$ for G. caudata was higher than the activity observed for G. tikvahiae (43.3 $10^{-3} \mathrm{U} \mathrm{g} \mathrm{g}^{-1}$; Hwang et al. 1987) and G. tenuistipitata (43.0 $10^{-3} \mathrm{U} \mathrm{g}^{-1}$; Lopes et al. 1997) and lower than that of G. chilensis $\left(253.210^{-3} \mathrm{U} \mathrm{g}^{-1}\right.$; Chow et al. 2004). All differences found between the species reinforce the need of a previous standardized protocol and characterization of NR activity for each studied species.

The NR activity of G. caudata showed an oscillation during 24 hours, with maximal peak after 10 hours of light $\left(60 \pm 1.3310^{-3} \mathrm{U} \mathrm{g}^{-1}\right)$, coinciding with maximal irradiances observed in natural environments between 12:00 to 15:00 pm. This peak during the light phase evidences a light-dependent activation/inactivation response as have been reported by Lillo et al. (2004) for land plants.

Our results showed that G. caudata NR is active mainly during the light phase of the 24 hours cycle. In higher plants, light has been showed to induce NR activity in two ways, (1) rapid (minutes) induction, modulating the activation of pre-existing protein, and (2) slow (hours, days), inducing NR gene expression, in this case, the effect of the light could be replaced by glucose (Lillo et al. 2004). Based on what is known for higher plants, glucose was added to the growing media to see its effect on NR activity. Fries (1963) showed for red algae (including six species) that glucose and other sugars have an effect on algal growth. Yokoya (1996) showed that an increment in growth and morphogenesis occurred in Gracilariopsis tenuifrons and Grateloupia dichotoma with the addition of $1 \%$ sucrose, although its presence in the culture media was not essential. When glucose was added to G. caudata cultures 1 hour before the NR assay, no difference in enzymatic activity was observed, indicating that glucose does not affect directly the modulation of the NR enzyme. When glucose was added 24 hours before the NR assay, it was observed an increase in the enzymatic activity indicating that glucose is activating the NR through a slow response mechanism (i.e. gene expression and/or new synthesis of the protein). These results indicate that light is one of the major regulating factors of NR activity and that the photosynthesis could be modulating NR gene expression through glucose production.

Glucose mimics the effect of light on NR, inducing its activity both during the light and dark phases. This could be explained by inducing protein dephosphorylation, as evidenced by Iglesias-Bartolomé et al. (2004). Reports on the mechanisms involved in sugar regulation of phosphorylation state on NR are scarce for macroalgae. Regulatory mechanisms of the enzymatic activity include complex modulator processes to optimize nitrogen assimilation and prevent the formation of toxic products. The post-translational control of NR by phosphorylation is the most important controlling mechanism to avoid this deleterious accumulation (Lillo et al. 2004), but there are many aspects still to be solved, opening an interesting research area to elucidate the signalling mechanism that modulates the nitrogen assimilatory pathway in macroalgae.

Acknowledgements - Financial support and scholarships were provided by CNPq (Brazil), IFS (Sweden), and Fapesp (Brazil). We acknowledge Rosário Petti for technical assistance.

\section{References}

BERGES, J.A. \& HARRISON, P.J. 1995. Relationships between nitrate reductase activity and nitrate incorporation under steady-state light or nitrate limitation in the marine diatom Thalassiosira pseudonana (Bacillariophyceae). Journal of Phycology 31:85-95.

CAMPBELL, W.H. 1999. Nitrate reductase structure, function and regulation: bridging the gap between biochemistry and physiology. Annual Review of Plant Physiology and Plant Molecular Biology 50:277-303.

CHAPMAN, D.J. \& HARRISON, P.J. 1988. Nitrogen metabolism and measurement of nitrate reductase activity. In Experimental phycology. A laboratory manual (C.S. Lobban, D.J. Chapman \& B. Kremer, eds.). Cambridge University Press, Cambridge, p.196-202.

CHOW, F. 2002. Atividade in vitro e regulação da enzima nitrato redutase na alga vermelha Gracilaria chilensis (Gracilariales, Rhodophyta). Tese de doutorado, Instituto of Biociências, Universidade de São Paulo, São Paulo. 
CHOW, F., OLIVEIRA, M.C. \& PÉDERSEN, M. 2004. In vitro assay and light regulation of nitrate reductase in red alga Gracilaria chilensis. Journal of Plant Physiology 161:769-776.

CRAWFORD, N.M. \& ARST JUNIOR, H.N. 1993. The molecular genetics of nitrate assimilation in fungi and plants. Annual Review of Genetics 27:115-146.

EDMUNDS JUNIOR, L.N. 1988. Cellular and molecular bases of biological clocks. Springer-Verlag, New York.

EDWARDS, P. 1970. Illustrated guide to the seaweeds and sea grasses in the vicinity of Porto Aransas, Texas. Contribution in Marine Science Austin 15:1-228.

FRIES, L. 1963. On the cultivation of axenic red algae. Physiologia Plantarum 16:695-708.

HOSHAW, R.W. \& RODOWSKI, J.R. 1973. Methods for the microscopic algae. In Handbook of phycological methods. Culture methods and growth measurements. (J.R. Stein, ed.). Cambridge University Press, Cambridge, p.53-68.

HUBER, J.L., HUBER, S.C., CAMPBELL, W.H. \& REDINBAUGH, M.G. 1992. Reversible light/dark modulation of spinach leaf nitrate reductase activity involves protein phosphorylation. Archives of Biochemistry and Biophysics 296:58-65.

HUPPE, H.C. \& TURPIN, D.H. 1994. Integration of carbon and nitrogen metabolism on plant and algal cells. Annual Review of Plant Physiology and Molecular Biology 45:577-607.

HURD, C.L., BERGES, J.A., OSBORNE, J. \& HARRISON, P.J. 1995. An in vitro nitrate reductase assay for marine macroalgae: optimization and characterization of the enzyme for Fucus gardneri (Phaeophyta). Journal of Phycology 31:835-843.

HURLBERT, S.H. 1984. Pseudoreplication and the design of ecological field experiments. Ecological Monographs 54:187-211.

HWANG, S.P.L., WILLIANS, S.L. \& BRINKHUIS, B.H. 1987. Changes in intertidal dissolved nitrogen pools as related to nitrate uptake and assimilation in Gracilaria tikvahiae McLachlan (Rhodophyta). Botanica Marina 30:11-19.

IGLESIAS-BARTOLOMÉ, R., GONZÁLEZ, C.A. \& KENIS, J.D. 2004. Nitrate reductase dephosphorylation is induced by sugar and sugar-phosphate in corn leaf segments. Physiologia Plantarum 122:62-67.

JACKSON, J.B. 1991. The proton-translocating NAD transhydrogenase. Journal of Bioenergetic and Biomembranes 23:715-741.

KAISER, W.M. \& BRENDLE-BEHNISCH, E. 1991. Rapid modulation of spinach leaf nitrate reductase activity by photosynthesis. I. Modulation in vivo by $\mathrm{CO}_{2}$ availability. Plant Physiology 96:363-367.

LEA, P.J. \& LEEGOOD, R.C. 1995. Plant biochemistry and molecular biology. John Wiley \& Sons, New York.

LEATHERBARROW, R.J. 1990. Use of nonlinear-regression to analyse enzyme kinetic data - application to situations of substrate contamination and background subtraction. Analytical Biochemistry 184:274-278.
LEWIN, J. 1966. Silicon metabolism in diatoms. V. Germanium dioxide, a specific inhibitor of diatom growth. Phycologia 6:1-12.

LILLO, C., MEYER, C., LEA, U.S., PROVAN, F. \& OLTEDAL, S. 2004. Mechanism and importance of post-translational regulation of nitrate reductase. Journal of Experimental Botany 55:1275-1282.

LOBBAN, C.S. \& HARRISON, P.J. 1994. Seaweed ecology and physiology. Cambridge University Press, Cambridge.

LOPES, P.F., OLIVEIRA, M.C. \& COLEPICOLO, P. 1997. Diurnal fluctuation of nitrate reductase activity in the marine red alga Gracilaria tenuistipitata (Rhodophyta). Journal of Phycology 33:225-231.

NAKAMURA, Y. \& IKAWA, T. 1993. Purification and properties of NADH: nitrate reductase from alga Porphyra yezoensis. Plant and Cell Physiology 34:1239-1249.

OLIVEIRA, E.C. \& ALVEAL, K.V. 1990. The mariculture of Gracilaria (Rhodophyta) for the production of agar. In Introduction to applied phycology (I. Akatsuka, ed.). Academic Publishing, The Hague, Netherlands, p.553-564.

OLIVEIRA, E.C. \& PLASTINO, E.M. 1994. Gracilariaceae. In Biology of economic algae (I. Akatsuka, ed.). SBP Academic Publishing, The Hague, Netherlands, p.185-226.

OLIVEIRA, E.C., PAULA, E.J., PLASTINO, E.M. \& PETTI, R. 1995. Metodologías para el cultivo no axénico de macroalgas marinas in vitro. In Manual de métodos ficológicos (K. Alveal, M.E. Ferrario, E.C. Oliveira \& E. Sar, eds.). Universidad de Concepción, Concepción, Chile, p.429-447.

RAMUS, J. 1981. The capture and transduction of light energy. In The biology of seaweeds (C.S. Lobban \& M.J. Wynne, eds.). University of California Press, Berkeley, p.458-492.

ROSSA, M.M. 1999. A luz como fator de regulação da atividade enzimática da nitrato redutase (NR) e superóxido dismutase (SOD) em Gracilariopsis tenuifrons (Rhodophyta). Dissertação de mestrado, Instituto of Biociências, Universidade de São Paulo, São Paulo.

SOLOMONSON, L.P. \& BARBER, M.J. 1990. Assimilatory nitrate reductase: functional properties and regulation. Annual Review of Plant Physiology and Plant Molecular Biology 41:225-253.

THOMAS, T.E. \& HARRISON, P.J. 1988. A comparison of in vitro and in vivo nitrate reductase assays in three intertidal seaweeds. Botanica Marina 31:101-107.

YOKOYA, N.S. 1996. Controle do crescimento e da morfogênese por auxinas e citocininas em três espécies de rodofíceas: Gracilariopsis tenuifrons, Grateloupia dichotoma e Solieria filiformis. Tese de doutorado, Instituto of Biociências, Universidade de São Paulo, São Paulo.

ZAR, J.H. 1999. Biostatistical analysis. Prentice Hall, Englewood Cliffs, New Jersey. 